\author{
Anna Szczepaniak-KozaK \\ Uniwersytet im. A. Mickiewicza w Poznaniu \\ Instytut Lingwistyki Stosowanej
}

\title{
Impoliteness in interlanguage requests of EFL learners in Poland
}

Ke y w ord s: interlanguage pragmatics; impoliteness; Polish EFL learners; requestive directness; mitigating/aggravating devices

Słowa klucze: pragmatyka interjęzykowa; niegrzeczność; Polacy uczący się języka angielskiego jako obcego; bezpośredniość próśb; środki modyfikujące

Brown and Levinson's $(1978,1987)$ theory is one of the most influential for investigating politeness phenomena. They define politeness as an intricate system people use to cushion threats to face, which is "the public selfimage that every member wants to claim for himself" (1987: 61). In order to maintain face, speakers have at their disposal a wide array of linguistic means, which are divided by the scholars into positive and negative politeness strategies.

After its publication, Brown and Levinson's theory found many applications, but also faced criticism. Some questioned, for example, the scholars' assumption that all speakers intend to save their interlocutors' face, and that all interaction participants strive for social harmony and equilibrium. This concept has also been criticized for its leaning towards a person's independence and freedom from imposition, which are values appreciated only in some cultures, e.g., the Anglo-Saxon one. Wierzbicka $(1985,2003)$ was one 
of the very first to oppose universal rules of politeness or conversation logics, based on her observations concerning how cultural values shape communication patterns, particularly taking into account linguistic data from Australian English and Polish. Criticism came also from Anglo-Saxon research circles. Lakoff (1989: 103) noticed that speakers do "not utilize politeness strategies where they would be expected, in such a way that the utterance can only almost plausibly be interpreted as intentionally and negatively confrontational," i.e., they intend to behave impolitely. Indeed, in reality humans choose to attack their interlocutor's face and deviate from acceptable polite behavior. For example, they may behave in a rude manner due to their ignorance of specific socially acceptable patterns of behavior. This happens with children during their process of enculturation, or adults who are not members of a particular society or culture, e.g., during acculturation.

The type of rudeness mentioned above, i.e., performed by a person who is unaware of being rude, is called by Kasper (1990: 208) unmotivated. However, when a person deliberately violates socially/culturally accepted norms, motivated rudeness occurs. Kasper (1990: 208-210) differentiates between three types of such rudeness: 1) taking place due to lack of control of one's emotions; 2) strategic, i.e., purposeful, rudeness observed, for example, in the courtroom behavior, when a direct verbal attack on the interlocutor takes place; and 3) ironic rudeness which is also purposeful but confrontational, without being verbally direct. All cases of intentional face-attack are considered cases of impoliteness invoking social conflict and disharmony (Culpeper et al. 2003: 1546).

Inspired by Brown and Levinson's theory of politeness, Culpeper (1996), Culpeper et al. (2003) and Bousfield (2008) propose an impoliteness framework including strategies of impoliteness. Bousfield and Culpeper (2008: 161) suggest interlocutors sometimes construct conflict on purpose, thus impoliteness is not a pragmatic failure but a linguistic behavior which is "strategic, systematic and sophisticated." Their main tenet is that, while Brown and Levinson notice that impoliteness is sometimes employed to sign intimacy and establish common ground, they do not seem to recognize that sometimes impoliteness may be a genuine act of attacking somebody's face. At the same time, Culpeper (1996) points out that Brown and Levinson's model does not address types or levels of impoliteness in interaction. The bald-on record 
strategy, he argues, is not the only strategy which interactants use to attack each other's face (Culpeper et al. 2003: 1547-1550).

According to Culpeper (2005: 38), "[i]mpoliteness comes about when: (1) the speaker communicates a face-attack intentionally, or (2) the hearer perceives and/or constructs behavior as intentionally face-attacking, or a combination of (1) and (2)." Impoliteness may come in two forms: mock (banter) and genuine (inherent). While mock impoliteness is not intended to cause offence but rather to amuse or evoke laughter, inherent impoliteness stands for speech acts which are not mitigated linguistically or contextually on purpose, and because of that they come across as rude (Culpeper 1996: 352). Bousfield (2008: 72) also defines impoliteness as FTAs delivered intentionally: 1) unmitigated, in contexts where mitigation is required; and/or 2) with deliberate aggression; that means with the face threat exacerbated, 'boosted' or minimized in some way to heighten the face damage inflicted.

Culpeper (1996: 356-357) augments this avenue of research by advancing a model of five super strategies of impoliteness parallel to Brown and Levinson's $(1978,1987)$ politeness model:

1. Bald-on record impoliteness - an attack on the hearer's face in a "direct, clear, unambiguous and concise way";

2. Positive impoliteness - an attack on the addressee's need to be approved of, aggravating attacks on the hearer's positive face, or desire to be liked;

3. Negative impoliteness - an attack on the addressee's need to be unimpeded;

4. Sarcasm or mock politeness - use of insincere politeness strategies;

5. Withholding politeness - not being polite where expected.

How language learners acquire politeness has been the subject of numerous studies, cf. Einsenstein and Bodman (1986), Ellis (1992), Marriott (1995), to name just a few. However, there is dearth of studies concerning impoliteness phenomena in interlanguage pragmatic competence of foreign language learners. To illustrate, out of a comprehensive list of 330 impoliteness bibliography items compiled by Culpeper (2009), only two reports could be classified as referring to this area of research, i.e., Beebe (1987) and Cashman (2006). Studies involving Polish learners of English are very rare, judging especially against the fact that there are significant differences between the 
two cultures, viz., Polish culture is directness-oriented and thus favors positive politeness, and Anglo-Saxon culture is indirectness-oriented and favors negative politeness. The studies of which I am aware and which operate on the borders of this area of research are: Solska's (2004) study of verbal irony perception and production in EFL/ESL learners, and Wiechecka's (2007) investigation of impoliteness and (in)directness.

Consequently, this paper intends to amend a considerable lacuna in interlanguage and impoliteness research, and investigates the ways impoliteness is visible in interlanguage pragmatics data coming from Polish EFL learners with special reference to informal aggravated requests. It needs to be highlighted, however, that the collected data are not analyzed cross-linguistically, i.e., with reference to the target language pragmatic norm, due to the fact that my primary concern in this study is at this stage about EFL learning and not

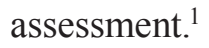

\section{The study design}

To investigate whether and how Polish learners of EFL develop their pragmatic competence with particular attention paid to rendering directness of requests and means of modifying their impositive force, linguistic data were collected by means of a Discourse completion task (DCT) involving an open response format, in a longitudinal study spanning over two years. The DCT included 15 different situations requiring a response in the form of a request. They were adapted from an original, longer task prepared by Liu (2007) with his permission. In this paper, due to limited space, only one situation is studied in detail, with a special focus on the participants' development of means for making the illocutionary intent of requests apparent and mitigating or aggravating their impact. Requests have been chosen because, according to May (2002: 120), they are speech acts which "embody an effort on the part of the speaker to get the hearer to do something." Thereby, they are impositive in nature and in some contexts impoliteness prone.

The requestive scenario puts the speaker in a situation where he or she asks an unknown person to stop blocking his or her view during a basketball match. The power status of the participants, who are strangers, is equal,

1 Samples collected in the third year of my research are planned to be juxtaposed with data obtained from native speakers of English. 
and the imposition of the request is moderate. Most importantly, the speaker clearly has the right to pose the request, and not much persuasion is required, but the satisfaction of the request depends on the discretion of the hearer. The situation was worded as follows, as reported by Liu (2007: 391-415): "You are watching a basketball game. A student you don't know comes and stands just in front of you blocking your view. You want to ask the student not to block your view."

The analysis takes into account whether and what type of alerters, external mitigation and lexical downgraders and upgraders are used, together with naming the strategy types for making requests. It juxtaposes data collected twice in October (2011, henceforth FY) and November (2012, henceforth SY). ${ }^{2}$ In this way, it was possible to study how the participating students intensify or soften their requests in terms of both the degree of modification applied and directness strategies in the head acts. Also, external mitigation is taken into account. In the final part of this paper, conclusions are drawn as to the types of impoliteness employed and whether there are changes across the duration of the study.

Because my intention was to obtain two maximally correlated samples of a relatively homogenous population, the study participants were $57 \mathrm{BA}$ students of bilingual philology studies at Adam Mickiewicz University in Poznań, Poland, who had not received metapragmatic instruction prior to FY. The participants were advanced students of English and German who received around 12 hours a week of instruction in English as long-term preparation for the professions of translator, teacher or intercultural mediator. By the end of their intensive philology training most of them become functionally multilingual: L1 Polish, L2 English, L3 German.

The table to code the collected data builds primarily on the coding manual designed by Blum-Kulka et al. (1989: 1-34, 277-289). ${ }^{3}$ Therefore, the requests are analyzed mostly in terms of their structure, taking into account not only the directness of the speech act but also the external and internal mitigation used together with alerters. Because the seminal model of Blum-Kulka et al. (1989) did not fully render the diversification of the collected samples,

2 Data coming only from FY are more thoroughly discussed in Szczepaniak-Kozak (2014). The research was continued in the third year (TY).

3 In general, their study indicated that native speakers of English prefer indirect strategies for request realization and that they prefer internal to external mitigation. 
especially because impoliteness was outside its authors' scope of interest, other models of analysis were consulted, e.g., designed by Rue and Qiao (2008: 52-57, 313-314) and Takahashi (2001: 199). In particular, the coding scheme for external mitigation devices needed to be extended to fully capture the complexity of the devices used to modify the illocutionary force of this particular speech act, i.e., mitigating and aggravating supportive moves.

Supportive moves which accompany the head act and modify its impact by softening (downgrading) it are called mitigating, and those inflaming (upgrading) the imposition of the act are called aggravating ones. While classification of and research on mitigating supportive moves is well established and known, there has been scant scientific discussion of aggravating devices. In this particular paper categorization of aggravating moves is conducted basing on Blum-Kulka et al. (1989: 1-34), Rue and Qiao (2008) and Sweeny and Hua (2010). All of the categories could be labeled genuinely impolite and the ones described below are based on negative impoliteness strategies:

- Threats which imply that action detrimental to the hearer will take place if the request is not satisfied;

- Reprimands which express scorn for some aspect of the hearer's behavior;

- Moralizing statements which pledge the hearer's adhering to widely accepted rules of good behavior and maintaining personal integrity;

- Aggressive interrogatives which emphasize, for example, the speaker's social position. They may also ridicule or challenge the hearer, his or her behavior or previously stated words.

\section{Research findings and discussion}

Below the results of the analysis are presented starting from linguistic means employed to alert the hearer's attention, followed by external mitigation moves, directness strategies and finally internal mitigation features. ${ }^{4}$ It needs to be added that in FY three students did not provide a response to this scenario. All examples are provided in their original form, i.e., spelling and grammatical errors occur in the examples on purpose.

4 A more thorough analysis of the data collected only in FY can be found in Szczepaniak-Kozak (2014). 


\subsection{Alerters}

Using an alerter in this particular scenario is justified as here an unknown student sits or stands with his back to the student who makes the request, so some form of attention getting is necessary. Altogether there was either one, or sometimes a double/triple, precursor in $72 \%$ samples in FY and $67.5 \%$ in SY. Out of those, the apologetic formula Excuse me appeared in FY 43.5\% and $28 \%$ in SY, while Sorry appeared in 18\% FY, 32\% in SY. In FY there appeared various informal alerters, in most cases greetings: Hey $15.3 \%, \mathrm{Hi}$ 5\% and Hello man, You in front $2.5 \%$. Although in SY the frequency of informal alerters increased to $40 \%$, they became uniform, i.e., most of them took the form of Hey, sometimes accompanied by dude. The occasional use of Hello! (ex. 1), both in FY and SY, is of particular interest. The students apparently used this interjection to suggest that the speaker is not paying attention to what is happening or is not behaving sensibly.

ex. 1. Hello, excuse me. I'm watching this. Hello! You're blocking view, it's really rude!

\subsection{External mitigation}

The impositive force of the requests differed considerably from sample to sample. This could have occurred due to individual preferences in speech act realization, or developmental differences in a particular student's interlanguage. Furthermore, it can be gleaned from the data that some students, especially in FY, wanted to make the addressee realize the seriousness of the situation by aggravating the illocutionary force of this request. That is to say, in FY out of 70 supportive moves 16 (22.8\%) were of the aggravating type, mostly reprimands (11; ex. 2), with a few aggressive interrogatives (3; ex. 4) and expressions of moralizing (2; ex. 3). Most interestingly, in other requestive scenarios in the DCT, aggravating mitigating moves were rare or not present at all.

ex. 2. Hey, you're staying in front of TV and I'm trying to watch the match. Can you seat on something?

ex. 3 Stand on the right. I don't see anything. It's unfair. 
ex. 4. Excuse me, do you think you are invisible? Would you like to take a seat next to me?

As to SY data, generally there were fewer external moves, i.e., 55, which means the students found that this situation requires less mitigation, which is indicative of changes in their interlanguage as well. The smaller degree, or lack, of mitigation in English is often interpreted as rude or impolite. It remains unclear, however, whether it is unmotivated or motivated rudeness. Additionally, in SY the students used impoliteness strategies less often and these were less varied. Reprimands were the only aggravators present in SY (18.5\%) while grounders increased their frequency to $68.5 \%$ (ex. 5). There were a few cases where it was difficult to tell whether a particular move was a grounder or reprimand, e.g., Can you move a little bit? I can't watch the game (SY). The sentences express the reason for the request but they are so succinct and direct that they could be considered examples of withholding politeness, i.e., the last strategy of impoliteness mentioned by Culpeper (1996). Similarly, I decided to classify the external move in ex. 5 as a reprimand because stating the obvious -other people watch a basketball game too- serves the purpose of guiding the hearer to recognize what everybody should know. And showing that a person does not know something obvious stands for telling the person that he or she is not mindful or concerned. Finally, the expression of gratitude Thanks, in ex. 6, is normally considered a downgrading modifier, however, when placed in the final utterance position, especially when accompanied by three exclamation marks, it evokes the impression that the speaker wants to abruptly finish the exchange, as if the speaker did not want to continue the conversation any longer. Thanks was used in this way both in FY and SY.

As mentioned above, the remaining external moves both in FY and SY were of the supportive type, most of which were grounders (ex. 7). The remaining mitigating moves in FY and SY were apologies, I am (so) sorry (FY), expressions of gratitude and one promise of reward (SY, ex. 8).

ex. 5. Hi, I am watching a basketball game. Please, don't blocking me view.

ex. 6. Hey, you! Could you stand aside? I'm watching the game. Thanks!!! ex. 7. I can't see anything. Could you change your place? 
ex. 8. Sorry, you're so tall and blocking my view, could you stand next to? It will be nice.

What transpires from the above findings is that, especially in FY, there is a clear distribution of the data, with aggravating moves on one side and grounders on the other with just two more types in between. The observed nonvariabity in such an imposing situation might indicate that some speakers chose impoliteness strategies, while others tried to soften the imposition by providing a reason or justification for the act, thus saving the positive face of the hearer. This could also be explained by Ogiermann's (2009: 31) ruminations concerning Poles in contact with strangers. When the social distance between speakers is considerable, Poles prefer anonymity "evidenced by lack of greetings, smiles or even eye-contact." That also resembles Culpeper's (1996) positive impoliteness strategy, which is interpreted by other nations as aggression, lack of manners or disrespect. When juxtaposed with the data collected in the remaining scenarios of the DCT, but not analyzed in this paper, cf. Szczepaniak-Kozak, 2013, 2014, 2015, a marked difference can be observed between pragmalinguistic forms produced in situations characterized by polarized degrees of social distance. In other words, these Polish students choose different external moves and different (im)politeness strategies depending on whether the addressee is a stranger or friend. This is aptly captured again by Ogiermann (2009: 31-32), in Polish "the variable of social distance [...] allows for a greater discrepancy than in Anglo-Saxon culture" in the performance of speech acts depending on whether Poles perform it in the public or private sphere. In public interactions, an example of which is the scenario analyzed in this writing, they may seem demanding, pushy, distant or simply rude.

\subsection{Requestive acts}

The collected requests were analyzed in terms of their level of (in)directness, which stands for "the relative length of the inferential path needed to arrive at an utterance's illocutionary point” (Blum-Kulka 1987: 133).

In FY, out of the 54 requests provided, starting from the most direct strategies, there were eight mood derivables (15\%, ex. 9), 38 query preparatories (70\%, ex. 10), one permission question, one mitigated-preparatory statement (ex. 11) and three mitigated-want statements (ex. 12). There were also three 
examples of non-conventionally indirect requests (ex. 13) classified as strong hints. Most of them include multiple $I$ and you pronouns considered a bald-on strategy by Stewart (2004). Their use does not comply with the implicit rules of politeness, which says that in order to reduce "the form's level of coerciveness" the speaker is advised to avoid naming the hearer as actor (Blum-Kulka et al. 1989: 19). The excessive use of these pronouns is classified by Culpeper (1996) as a strategy of negative impoliteness, because it highlights the differences in the interactants' worldviews and evaluations of the event, which is the cause of irritation on the part of the speaker. In our example also the hearer is explicitly associated with this inconvenience to the speaker. One more example of impoliteness is presented in ex. 14, in which we can find two externally and internally mitigated mood derivables (one head act and its repetition).

ex. 9. Please do not block my view, because I'm actually watching this basketball game.

ex. 10. Could you move a bit. I can't see anything!

ex. 11. Excuse me. I would like to know, if you has nothing against moving a few steps to one of the sides, because I don't see anything.

ex. 12. Hello, I cannot see anything, cause you are standing right in front off my face. I'd be grateful, if you could move a little bit.

ex. 13. Sorry but you aren't the one who is watching the basketball game now.

ex. 14. Excuse me, I'm watching a match. Don't stay in front of me please, because I don't see anything. So if it's possible stay near.

In SY the students used fewer direct strategies. Mood derivables constituted $10 \%$ and the students displayed a clear preference for the query preparatory $(84 \%)$. There were very rare examples of other indirect strategies, viz., one permission question (conventionally indirect), and one non-conventionally indirect strong hint. Because most of the requests are formed by means of the mood derivable or interrogatories with could/can you, and there were no biclausal mitigating strategies used, the samples in SY sound very confrontational. All in all, despite the fact that the SY requests seem more indirect and conventional, in fact the students' irritation, and perhaps impoliteness, is observable in the increased frequency of you and shorter forms of the speech act. 


\subsection{Internal mitigation}

The findings concerning request strategies take on greater significance when we combine them with an analysis of interlanguage internal mitigation devices, i.e., "elements within a head act which are not essential for its understanding (Blum-Kulka et al. 1989: 281). They come in two types. Those softening the message are called downgraders, and those intensifying its coerciveness are called upgraders (Sweeney, Hua 2010: 486-7). The repertoire of downgraders is extensive: interrogative constructions, tenses, conditionals, negated sentences, lexical downtoners (politeness markers, understaters, hedges, indefinite pronouns, cajolers, consultative devices, etc.). As far as upgraders are concerned, the imposition of a request can be strengthened by intensifiers, expletives or time intensifiers.

Generally, in my data the respondents displayed an underuse of lexical/ phrasal downgrading or upgrading, which is a typical feature of interlanguage pragmatic competence (cf. Szczepaniak-Kozak 2013, 2014, 2015). Some researchers argue that due to this observable lack of or insufficient level of internal mitigation, interlanguage requests tend to produce a distorted, non-native-like pragmatic effect, and are perceived as abrupt (EconomidouKogetsidis 2009: 93).

In FY the requests were most often formed as ability questions formulated with the past simple tense could with a very low frequency of conditional constructions (2; ex. 16) and no negated interrogatives. The high frequency of ability questions in the past tense (48\%; ex. 15) could result from positive transfer from the students' first language or overgeneralization (Ellis 2003). However, the case is different with the fourteen ability questions (26\%) formed with the present simple tense can, which would be considered a marked form in contrast to the requests with could. Clearly, can used in preparatory questions in this particular constellation of sociopragmatic variables should be considered as a means of increasing the imposition of the request. In SY the students stick to the same pattern as interrogatives, i.e., could constituted $55 \%$ and query preparatories with can constituted $26 \%$. Hence, in SY, too, this modal verb remained a syntactic device intensifying the illocutionary force of the utterance. 
ex. 15. Sorry buddy, could you sit down somewhere, you are blocking my view.

ex. 16. I would be grateful, if you could move a little bit.

The above conclusion becomes more valid when we consider the dearth of other internal mitigating devices in the requests provided. In detail, the dominant category were adverbials of place in both years, which is a natural consequence of the fact that this request asks a stranger to change his or her place. The second most frequent category in FY was the understater a little bit (13) or a few steps (2). Interestingly, the requests were seldom accompanied by please (ex. 17). This politeness marker appears in $18.5 \%$ of the requests in FY and in every tenth request in SY (10,5\%). Finally, the remaining categories of internal mitigation in FY were: one syntactic downgrader (aspect) I would like you to..., three cases of giving option with or (ex. 17), one intensifier really, eight indefinite pronouns some, which could be classified as hedges, two downtoners and one appealer. In SY the remaining internal modifiers were two negations of a preparatory condition, and one option giving (ex. 18). The lack of clauses expressing options available to the hearer, thus denying the hearer a choice, can be interpreted as impolite. When we take into account that in other scenarios included in the DCT (cf. Szczepaniak-Kozak, 2013, 2014, 2015) option giving occurred very frequently as a politeness strategy, the findings of this analysis acquire greater importance.

ex. 17. Sorry, could you move a step to the side, please? You're blocking my view.

ex. 18. Sorry, can you let me watch the match and go a little bit left or right?

\section{Summary of research findings and final remarks}

The findings presented above allow us to formulate a few conclusions concerning interlanguage impoliteness strategies and mitigation in Polish EFL learners. In the present study impoliteness is multifaceted and noticeable on levels 3-5 as defined by Culpeper (1996), viz., attacking the addressee's need to be unimpeded, sarcasm or mock politeness - use of insincere politeness strategies or withholding politeness. Some of the requests, especially those 
coming from FY, were noticeably impolite because they were externally mitigated by aggravators (reprimands and aggressive interrogatives). Additionally, in both years, every fourth request was formed by the marked form can and alerters marked impoliteness by personalized negative references, e.g., you in front, you man or hello, giving vent to the speaker's irritation. These results are not only examples of impoliteness strategies, viz., Culpeper's inappropriate identity markers, but also support Koike's (1989: 287) comment on the dissociation of pragmatics and grammar in adults learning foreign languages, "since the grammatical competence cannot develop as quickly as the already present pragmatic concepts require, the pragmatic concepts are expressed in ways conforming to the level of grammatical complexity acquired."

In SY the students toned down their language and used fewer and less diversified external aggravating moves and fewer personalized negative assertions. However, this does not mean that politeness strategies replaced impoliteness ones. On the contrary, in SY inherent impoliteness stands for speech acts which were unmitigated linguistically or contextually, in contexts where mitigation is required. ${ }^{5}$ Irony or scorn remained a frequent impoliteness strategy. Simultaneously, explicitly putting the hearer in the position of blame by means of you became the most frequent negative impoliteness strategy. That may indicate that the development of pragmatic competence in EFL learners takes a path which is different from that characteristic of native English acquisition. However, for the time being this is only my educated guess as only data from TY of my study are going to be contrastively analyzed against samples collected from native speakers of English.

It needs to be mentioned that due to the methodological constraints characteristic of the DCT, ${ }^{6}$ it was sometimes difficult to establish what function a particular response served. For example, sometimes it was not clear whether a particular external mitigating move was a grounder or reprimand. In a few cases the students heightened the illocutionary force by means of orthographic emphasis, e.g., exclamation marks, suspension points to mark silence or expectance of the hearer's immediate reaction to the request. Additionally, in

${ }^{5}$ Liu (2007) reports that native speakers provided in the same questionnaire less direct and more mitigated forms; the exemplary form given by them was: Sorry, you are blocking my view, would you please take another place?

${ }^{6}$ I write more on this in Szczepaniak-Kozak (2013). 
research employing a DCT it is hard to gather empirical data to decide whether the impoliteness noticeable in the collected data is mock or genuine. This warrants further investigation by means, for example, of interviews or perception questionnaires. Impoliteness was also visible in the wording of some requests, e.g., go away, move (yourself), you are not transparent (grounder), which could be the subject of a study based on corpus analysis. Finally, it needs to be acknowledged that, due to space constraints, in the above analysis I did not take into consideration individual or sociolinguistic influences on the collected longitudinal data. A separate study would be necessary and useful to discuss how the samples of learner language differ in terms of, for example, the individual learner's gender, sociocultural background, past learning history, cognitive and affective factors.

\section{Bibliography}

BeEBe L., 1997, Rude awakenings: Ways of responding to rudeness, in: L.F. Bouton (ed.), Pragmatics and Language Learning, Urbana-Champaign: University of Illinois, p. 1-35.

Blum-KulKa S., 1987, Indirectness and politeness in requests: Same or different, Journal of Pragmatics 11, p. 131-146.

Blum-Kulka S., House J., Kasper G. (eds.), 1989, Cross-cultural Pragmatics: Requests and Apologies, Norwood, N.J.: Ablex.

Bousfield D., 2008, Impoliteness in Interaction, Amsterdam: Benjamins.

Bousfield D., CulpePer J., 2008, Impoliteness: Eclectism and diaspora. An introduction to the special edition, Journal of Politeness Research 4, p. 161-168.

Brown P., Levinson S., 1978, Universals of language usage: Politeness phenomena, in: E.N. Goody (ed.), Questions and Politeness, Cambridge: Cambridge University Press, p. 56-234.

Brown P., Levinson S., 1987, Politeness: Some Universals in Language Use. Cambridge: Cambridge University Press.

Cashman H., 2006, Impoliteness in children's interactions in a Spanish/English bilingual community of practice, Journal of Politeness Research 2(2), p. 217-246.

Culpeper J., 1996, Towards an anatomy of impoliteness, Journal of Pragmatics 25, p. 349-367.

Culpeper J., 2005, Impoliteness and entertainment in the television quiz show: The Weakest Link, Journal of Politeness Research 1, p. 35-72. 
CULPEPER J., 2009, Impoliteness: Using and understanding the language of offence [on-line],http://www.lancaster.ac.uk/fass/projects/impoliteness/bibliography.htm, [25.07.2014].

Culpeper J., Bousfield D., Wichmann A., 2003, Impoliteness revisited: with special reference to dynamic and prosodic aspects, Journal of Pragmatics 35(10/11), p. $1545-1580$.

ECONOMIDOU-Kogetsidis M., 2009, Interlanguage request modification: The use of lexical/phrasal downgraders and mitigating supportive moves, Multilingua 28, p. $79-112$.

Einsenstein M., Bodman J.W., 1986, 'I very appreciate': Expressions of gratitude by native and non-native speakers of American English, Applied Linguistics 7, p. 167-185.

Ellis R., 1992, Learning to communicate in the classroom, Studies in Second Language Acquisition 14(1), p. 214: 225.

Ellis R., 2003, The Study of Second Language Acquisition, Oxford: Oxford University Press.

Kasper G., 1990, Linguistic politeness. Current research issues, Journal of Pragmatics 14, p. 193-218.

KoIKE, D., 1989, Pragmatic competence and adult L2 acquisition: Speech acts in interlanguage, The Modern Language Journal 73, p. 279-289.

LAKofF R., 1989, The limits of politeness: Therapeutic and courtroom discourse, Multilingua 8, p. 101-129.

LiU J., 2007, Development of a pragmatics test for Chinese EFL learners, Language Testing 24 (3), p. 391-415.

MARriotT, H., 1995, The acquisition of politeness patterns by exchange students in Japan, in: B. Freed (ed.), Second Language Acquisition in a Study Abroad Context, Amsterdam: Benjamins, p. 197-224.

May J. L., 2002, Pragmatics. An Introduction, Oxford: Blackwell.

Ogiermann E., 2009, On Apologising in Negative and Positive Politeness Cultures, Amsterdam: Benjamins.

Rue Y-J, Qiao G., 2008, Request Strategies: A Comparative Study in Mandarin Chinese and Korean, Amsterdam: Benjamins.

Solska A., 2004, Verbal irony and the EFL/ESL learner, in: J. Arabski (ed.), Pragmatics and Language Learning, Kraków: Universitas, p. 205-218.

Stewart M., 2004, Politeness in Britain: 'It's only a suggestion...', in: L. Hickey, M. Stewart (eds.), Politeness in Europe, Clevedon: Multilingual Matters, p. 116-129

Sweeney E., Hua Z., 2010, Accommodating toward your audience: Do native speakers of English know how to accommodate their communication strategies toward nonnative speakers of English?, Journal of Business Communication 47(4), p. 477-504. 
Szczepaniak-Kozak A., 2013, The relation between linguistic proficiency and pragmatic appropriacy, in: I. Headlandová Kalischová, M. Němec (eds.), English as the Lingua Franca of the Modern World, Brno: Masaryk University Press, p. 39-54.

SzczepaniaK-KozAK A., 2014, Interlanguage pragmatics: A study into the acquisition of pragmatic competence in EFL context, in: S. Adamczak-Krysztofowicz, A. Szczepaniak-Kozak (eds.), Kultur-Kommunikation-Kreativität-Reflexivität, Frankfurt a.M.: Peter Lang, p. 59-76.

Szczepaniak-KozaK A., 2015, Interlanguage pragmatics: Analysis of requests produced by EFL learners in academic context, in: M. Murawska, E. WąsikiewiczFirlej, A. Szczepaniak-Kozak (eds.), Discourses in Co(n)text - The Many Faces of Specialized Discourse, Newcastle Upon Thyne: Cambridge Scholars Publishing, p. 352-383.

TAKAhashi S., 2001, Input enhancement in developing pragmatic competence, in:

K. Rose, G. Kasper (eds.), Pragmatics in Language Teaching, Cambridge: Cambridge University Press, p. 171-199.

WiecheCKA A. 2007, (Im)politeness and (in)directness, in: J. Arabski, D. Gabryś-Barker, A. Łyda (eds.), Studies in Language and Methodology of Teaching Foreign Languages, Katowice: Para, p. 248-260.

WierzBicka A., 1985, Different cultures, different languages, different speech acts: Polish vs. English, Journal of Pragmatics 9(2/3), p. 145-178.

Wierzbicka A., 2003, Cross - Cultural Pragmatics: The Semantics of Human Interaction, Berlin/New York: Mouton de Gruyter.

\section{Niegrzeczność w prośbach formułowanych przez Polaków uczących się języka angielskiego jako obcego}

(streszczenie)

Celem artykułu jest poszerzenie stanu wiedzy na temat nabywania kompetencji pragmatycznej w języku angielskim jako obcym ze szczególnym uwzględnieniem niegrzeczności językowej. Autorka analizuje jeden komponent pragmatyki interjęzykowej, tj. prośby - dyrektywne akty mowy, i doszukuje się tendencji charakterystycznych dla Polaków uczących się tego języka w obrębie strategii użytych do wyrażenia prośb oraz środków modyfikujących ich dolegliwość (ang. imposition). Dane językowe zebrano w badaniu podłużnym za pomocą kwestionariusza sytuacyjnego. Analiza próśb skupia się na przejawach niegrzeczności językowej na czterech poziomach: powitania, strategie wyrażania bezpośredniości próśb, wewnętrzne i zewnętrzne środki modyfikujące. Na tej podstawie autorka wyciąga wnioski na temat tendencji rozwojowych w kompetencji pragmatycznej uczestników badania w obrębie niegrzeczności językowej. 